\title{
Glycosylation of glycolipids in cancer: basis for development of novel therapeutic approaches
}

\section{Jose L. Daniotti *, Aldo A. Vilcaes, Vanina Torres Demichelis, Fernando M. Ruggiero and Macarena Rodriguez-Walker}

Facultad de Ciencias Químicas, Departamento de Química Biológica, Centro de Investigaciones en Química Biológica de Córdoba (CIQUIBIC, UNC-CONICET),

Universidad Nacional de Córdoba, Córdoba, Argentina

\section{Edited by:}

Adriane Regina Todeschini,

Universidade Federal do Rio de

Janeiro, Brazil

\section{Reviewed by:}

Olivier Micheau, Institut National de la

Santé et de la Recherche Médicale,

France

Leonardo Freire De Lima,

Universidade Federal do Rio de

Janeiro, Brazil

\section{*Correspondence:}

Jose L. Daniotti, Facultad de Ciencias Químicas, Departamento de Química Biológica, Centro de Investigaciones en Química Biológica de Córdoba (CIQUIBIC, UNC-CONICET), Universidad Nacional de Córdoba, Haya de la Torre y Medina Allende, Ciudad Universitaria, Córdoba 5000,

Argentina

e-mail:daniotti@fcq.unc.edu.ar
Altered networks of gene regulation underlie many pathologies, including cancer. There are several proteins in cancer cells that are turned either on or off, which dramatically alters the metabolism and the overall activity of the cell, with the complex machinery of enzymes involved in the metabolism of glycolipids not being an exception. The aberrant glycosylation of glycolipids on the surface of the majority of cancer cells, associated with increasing evidence about the functional role of these molecules in a number of cellular physiological pathways, has received considerable attention as a convenient immunotherapeutic target for cancer treatment. This has resulted in the development of a substantial number of passive and active immunotherapies, which have shown promising results in clinical trials. More recently, antibodies to glycolipids have also emerged as an attractive tool for the targeted delivery of cytotoxic agents, thereby providing a rationale for future therapeutic interventions in cancer. This review first summarizes the cellular and molecular bases involved in the metabolic pathway and expression of glycolipids, both in normal and tumor cells, paying particular attention to sialosylated glycolipids (gangliosides). The current strategies in the battle against cancer in which glycolipids are key players are then described.

Keywords: gangliosides, glycolipids, glycosylation, cancer, immunotherapy, antibodies, immunotoxin

\section{INTRODUCTION}

The aberrant and elevated expression of glycolipids has been demonstrated on the cell surface of different types of cancer cells, with these observations having opened the gate to the development of traditional immune-based treatment strategies in the battle against cancer. In general, glycolipid vaccines have failed to have a significant effect on tumor development. More recently, associated with a better comprehension about the expression, function, and membrane organization of glycolipids as well as the use of modern technologies, new immunotherapies have been developed. These therapies involve, for instance, arming monoclonal antibodies against tumor glycolipids with toxins or cytotoxic drugs; the generation of new glycolipid-specific chimeric antigen receptors in human primary T-lymphocytes; novel therapies using anti-idiotype monoclonal antibodies to sialosylated glycolipids (gangliosides); genetically engineered monoclonal antibodies to gangliosides with improved efficacy to induce antibody-mediated cellular cytotoxicity (ADCC); and complement-dependent cytotoxicity (CDC), among other original and promising immunotherapies.

Multi-institutional consortiums have been recently created to identify and quantitate all major and many minor lipids (lipidomic) $^{1}$ and glycans (glycomic) $)^{2}$ species present mainly in

${ }^{1}$ http://www.lipidmaps.org

${ }^{2} \mathrm{http}: / /$ www.functionalglycomics.org mammalian cells, as well as to quantitate the changes in these species in response to perturbation. These initiatives are providing an enormous amount of information, which will certainly be of great help in the search for new targets in the treatment of cancer.

\section{GLYCOLIPID STRUCTURE AND SYNTHESIS}

Glycolipids are lipids that have a covalently attached carbohydrate. Based on the type of lipid, they can be categorized into three main groups: glycoglycerolipids, glycosylphosphatidylinositols, and glycosphingolipids (GSLs). Mammalian GSLs begin with either glucose (GlcCer) or galactose (GalCer) attached in $\beta$-linkage to the 1-hydroxyl of ceramide (Cer) or sphingoid. GalCer can eventually be sulfated to produce acidic GSLs, referred to as sulfatides. When GlcCer is followed by addition of galactose, lactosylceramide (LacCer) is produced, which is at a branch point for formation of the root structure series (globo-, isoglobo-, lacto-, neolacto-, and ganglio-) (1). In particular, LacCer can be converted to both the neutral and acidic members of the ganglio-series by the sequential addition of different monosaccharide units, through catalytic processes mediated by type II integral membrane glycosyltransferases. Among the acidic members of the ganglio-series are found the gangliosides (Figures $\mathbf{1 A}, \mathbf{B}$ ), which are mono- or multi-sialosylated GSLs mainly located in the outer layer of the plasma membrane (PM) of vertebrate cells. In addition, they have been shown to be present on nuclear membranes, modulating the 


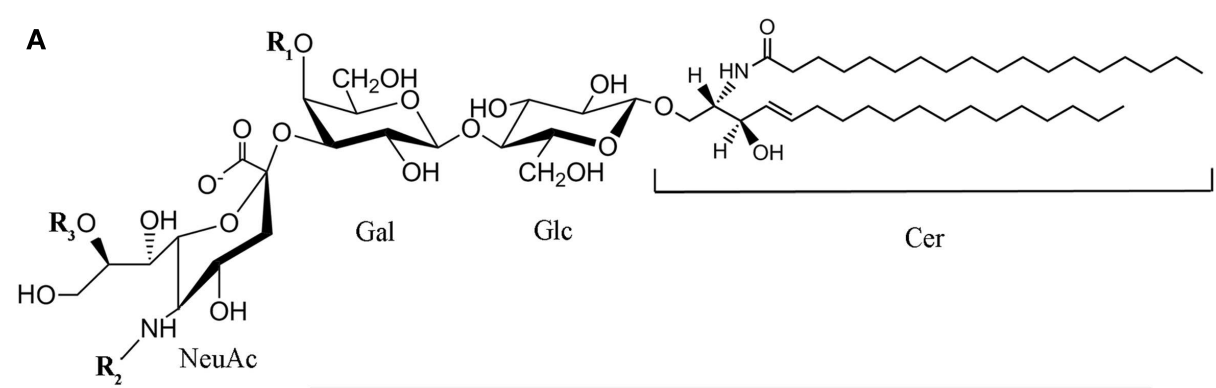

\begin{tabular}{|c|c|c|c|}
\hline & $\overline{\mathrm{R} 1}$ & $\mathbf{R 2}$ & $\mathbf{R 3}$ \\
\hline GM3 & $\mathrm{H}$ & $\mathrm{COCH}_{3}$ & $\mathrm{H}$ \\
\hline GM2 & $\operatorname{GalNAc}(\beta 1-4)$ & $\mathrm{COCH}_{3}$ & $\mathrm{H}$ \\
\hline GM1 & GalNAc $(\beta 1-4) \operatorname{Gal}(\beta 1-3)$ & $\mathrm{COCH}_{3}$ & $\mathrm{H}$ \\
\hline GD3 & $\mathrm{H}$ & $\mathrm{COCH}_{3}$ & $\operatorname{NeuAc}(\alpha 2-8)$ \\
\hline GD2 & $\operatorname{GalNAc}(\beta 1-4)$ & $\mathrm{COCH}_{3}$ & $\operatorname{NeuAc}(\alpha 2-8)$ \\
\hline 9-O-Ac-GD3 & $\mathrm{H}$ & $\mathrm{COCH}_{3}$ & $\operatorname{NeuAc}(\alpha 2-8)-9-O$-acetylated \\
\hline 9-O-Ac-GD2 & GalNAc( $\beta 1-4)$ & $\mathrm{COCH}_{3}$ & NeuAc( $(\alpha 2-8)-9-O$-acetylated \\
\hline 5- $N$-de-GM3 & $\mathrm{H}$ & $\mathrm{H}$ & $\mathrm{H}$ \\
\hline$N$-glycolyl-GM3 & $\mathrm{H}$ & $\mathrm{COCH}_{2} \mathrm{OH}$ & $\mathrm{H}$ \\
\hline Fucosyl-GM1 & $\begin{array}{r}\text { GalNAc( }(\beta 1-4) \operatorname{Gal}(\beta 1-3) \\
\operatorname{Fuc}(\alpha 1-2)\end{array}$ & $\mathrm{COCH}_{3}$ & $\mathrm{H}$ \\
\hline
\end{tabular}

B

$\begin{array}{lllll}\text { Glc-T } & \text { Gal-T1 } & \text { Sial-T1 } & \text { Sial-T2 } & \text { Sial-T3 }\end{array}$

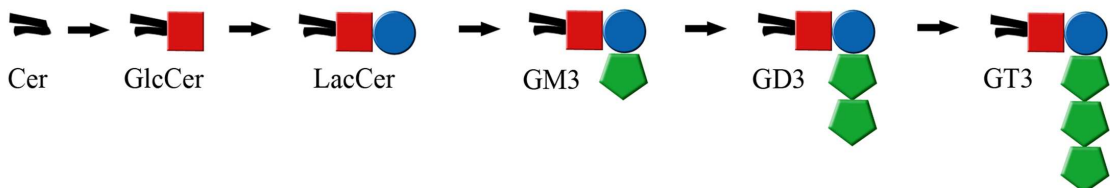

\begin{tabular}{|ll|}
\hline Glc \\
Gal \\
GalNAc \\
NeuAc \\
\hline
\end{tabular}
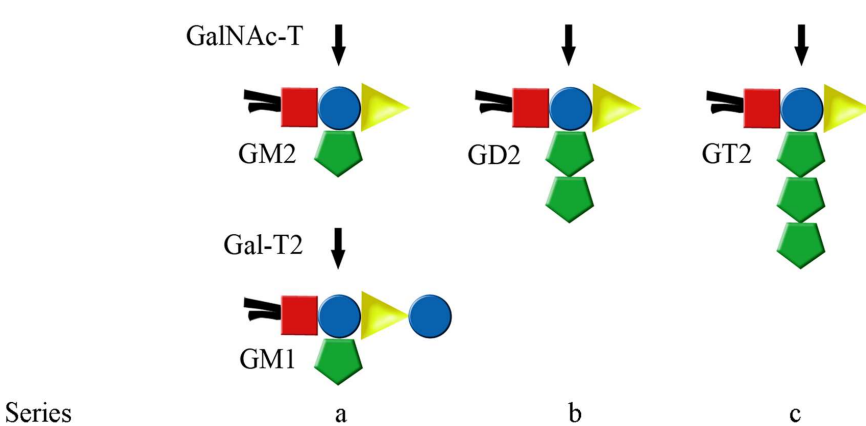

(B) Schematic representation of the main pathway of ganglioside biosynthesis. The full names of the abbreviations are indicated in the text

intranuclear calcium homeostasis (2). Gangliosides are expressed in cell-type and developmental-specific patterns, and are major components of nerve cells, where they may represent more than $10 \%$ of the total lipid content. Moreover, on the neuronal surface, they contribute more than $30 \%$ of the $N$-acetylneuraminic acid (Neu5Ac or sialic acid) (3-5).
After synthesis of the lipophilic ceramide tail in the endoplasmic reticulum (ER), it is then transported to the Golgi complex, where it is first catalytically converted to GlcCer through UDPGlc:ceramide glucosyltransferase (Glc-T) (Figure 2A). Then, most GlcCer can be transported back to the ER via a four-phosphate adaptor protein (FAPP2; a glycolipid-transport protein carrying 


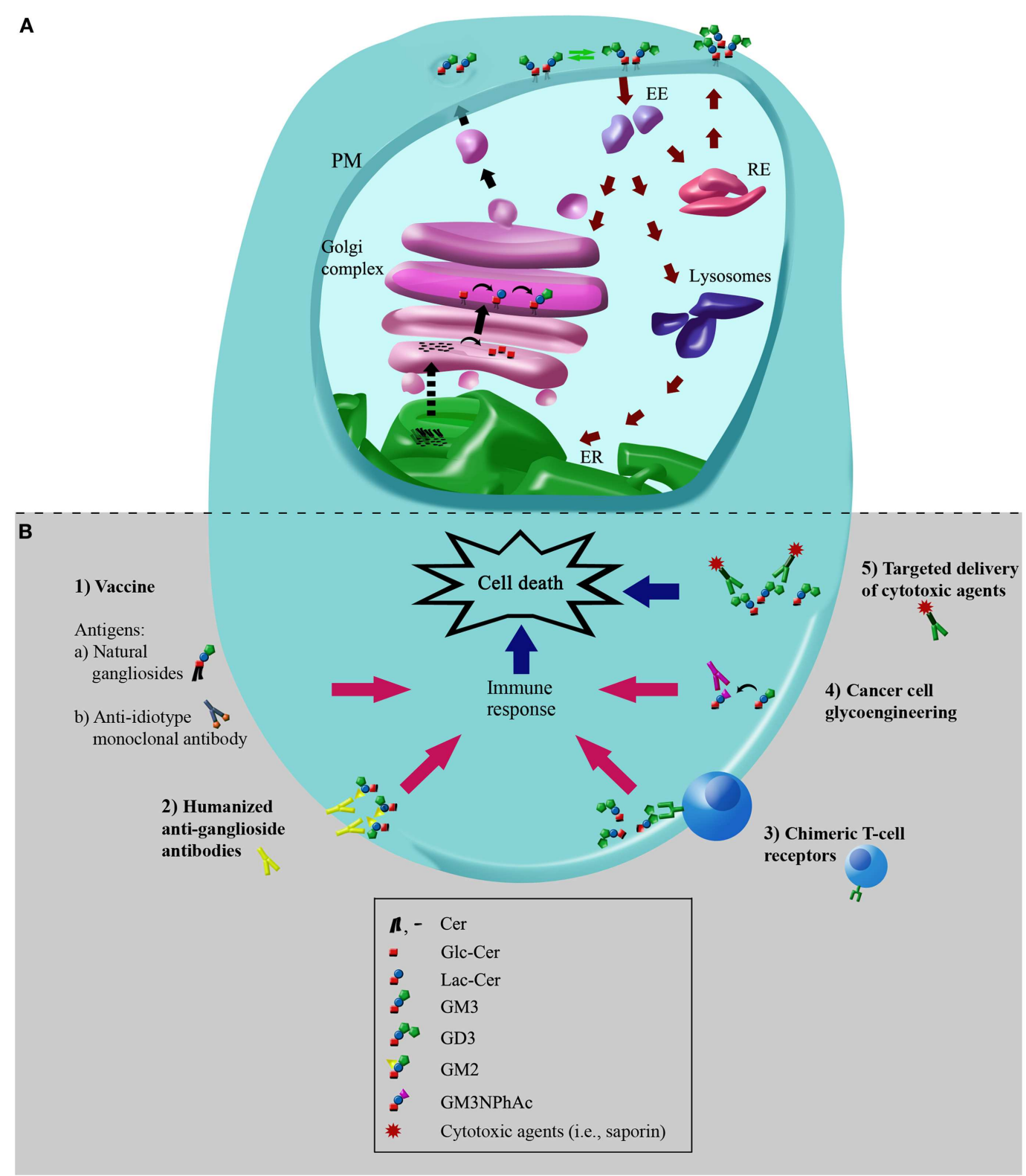

FIGURE 2 | Simplified scheme of metabolic pathways of plasma membrane-associated gangliosides: molecular targets for immunotherapies in cancer cells. (A) Simplified scheme of metabolic pathways and intracellular trafficking of gangliosides. Black arrows indicate the exocytic/biosynthetic pathway. Red arrows indicate the endocytic, recycling, and catabolic pathway. Dotted arrow indicates the vesicular or protein mediated transport of ceramide between endoplasmic reticulum (ER) and the Golgi complex. Green arrows indicate remodeling of glycosphingolipids by plasma membrane (PM)-associated glycohydrolases and glycosyltransferases. The hypothetical neobiosynthesis of GM3 at the Golgi complex and later transport to PM is indicated. De novo synthesized gangliosides or synthesized at the PM can undergo endocytosis through clathrin-independent vesicles (caveolae), and once internalized, they can be recycled back to the PM directly from recycling endosomes (REs) or sorted from early endosomes (EEs) to the Golgi complex, where they may then be reglycosylated, or transported to the lysosomes for total or partial degradation. The representation and colors of ganglioside structures are the same as in Figure 1. (B) Potential cancer immunotherapies using gangliosides as molecular targets. Schematic representation depicting the main cancer immunotherapies involving gangliosides: (1) vaccination with natural gangliosides or anti-idiotype monoclonal antibodies; (2) humanized anti-ganglioside antibodies; (3) chimeric T-cell receptors; (4) cancer cell glycoengineering and monoclonal antibody-mediated selective killing of cells; (5) targeted delivery of cytotoxic agents using specific antibodies to gangliosides. See text for more details. The schematic representation and colors of gangliosides structures are the same as those indicated in Figure $\mathbf{1}$. a PI4P binding domain), thereby entering the secretory pathway for further conversion to LacCer in the luminal face of the trans Golgi and TGN (6). Other evidence indicates that ceramide can be glycosylated to GlcCer on the cytosolic leaflet of the cis Golgi membranes by Glc-T, and also that FAPP2 is then required for the non-vesicular transport of GlcCer to distal Golgi 
compartments where it then translocates for further glycosylation steps leading to more complex GSLs synthesis, which eventually includes gangliosides (7). The synthesis of LacCer occurs by the action of UDP-Gal:glucosylceramide $\beta$-1,4-galactosyltransferase (Gal-T1), which transfers a galactose residue from UDP-Gal to GlcCer (Figure 1B). Then, monosaccharide units, including sialic acid, are transferred from the cognate sugar nucleotide donor to the glycolipid acceptors produced by the transferases acting in the preceding steps in the pathway of synthesis. Sialylated derivatives from LacCer are produced by the action of cytidine monophosphate (CMP)-NeuAc:LacCer $\alpha$-2,3-sialyltransferase (Sial-T1), CMP-NeuAc:GM3 $\alpha$-2,8-sialyltransferase (Sial-T2), and CMP-NeuAc:GD3 $\alpha-2,8$-sialyltransferase (Sial-T3), which specifically catalyze the formation of the gangliosides GM3, GD3, and GT3, respectively [ganglioside named according to Svennerholm (8)] (Figure 1B). LacCer, GM3, GD3, and GT3 are potentially converted to more complex gangliosides of the 0-, a-, b-, or c-series by sequential glycosylations catalyzed by UDP-GalNAc:LacCer/GM3/GD3/GT3 $\beta-1,4-N-$ acetylgalactosaminyltransferase (GalNAc-T), UDP-Gal:GA2/GM2 /GD2/GT2 $\beta$-1,3-galactosyltransferase (Gal-T2), CMP-NeuAc: GA1/GM1/GD1b/GT1c $\alpha$-2,3-sialyltransferase (Sial-T4), and CMP-NeuAc:GM1b/GD1a/GT1b/GQ1c $\quad \alpha$-2,8-sialyltransferase (Sial-T5). These transferases are non-redundant and specific, and catalyze a sugar transfer to a glycosyl acceptor that differs only in the number of sialic acids bound to the inner galactose [none (0-series), one (a-series), two (b-series), or three (c-series)]. Exceptionally, the ganglioside GM4 (NeuAca2,3Gal-Ceramide), a major component of the myelin, does not derive from LacCer. By the year 2004, 188 gangliosides with different carbohydrate structures had been identified in vertebrates (9).

After synthesis, gangliosides leave the Golgi complex via the lumenal surface of the transport vesicles (10). At the PM, the gangliosides can undergo endocytosis, be recycled back to the PM directly from early or recycling endosomes (REs), or sorted from endosomes at the Golgi complex, where they can then be reglycosylated or degraded at the lysosomal level (Figure 2A) $(5,11,12)$.

The level of expression and diversity of GSLs, including the gangliosides, can be controlled by regulating the sugar nucleotide and acceptor availability and by enzymatic degradation, as well as through the presence and activity of the glycosyltransferases that participate in their biosynthesis. Related to this, different types of regulation of glycosyltransferases have been reported, i.e., transcriptional, translational, or post-translational $(4,13,14)$. However, an additional type of regulation of GSL expression has been shown to occur at the PM level, due to PM-associated ectoglycohydrolases and glycosyltransferases $(3,15)$. In particular, an ectosialyltransferase (ecto-Sial-T2) recently described, it was able to sialylate GM3 exposed on its own cell or on the membrane of neighboring cells $(16,17)$.

\section{GANGLIOSIDE FUNCTION}

The development of genetically engineered mice with defects in distinct biosynthetic steps of ganglioside biosynthesis has revealed the critical role played by gangliosides in a number of important biological processes, especially in the nervous system (18, 19). Gangliosides have been implicated in many physiological processes, including growth, differentiation, migration, and apoptosis through modulating both cell signaling processes and cellto-cell and cell-to-matrix interactions (19-25). Moreover, gangliosides have been associated with a wide range of pathological processes, being receptors for viruses (i.e., simian virus 40), toxins (i.e., cholera; tetanus; and botulinum toxins), lectins, and antibodies $(11,26,27)$. Some antibodies to gangliosides, in particular to GM1, GD1a, and GQ1b, have been associated with a wide range of clinically identifiable acute and chronic neuropathy syndromes, including the Guillain-Barré and Miller-Fisher syndromes (28-31), with antibodies to tumor-associated gangliosides being considered to be potential therapeutic agents, which are described below in detail (32-34).

\section{GANGLIOSIDE EXPRESSION IN CANCER}

Sialic acid-containing GSLs, gangliosides, are present in normal tissues, but they are highly expressed in many human cancer cells (Table 1). This is associated with notorious changes in the repertory of expressed species, mainly by altered glycosyltransferase and glycohydrolase activities. GD2 is a disialoganglioside involved in cell growth and differentiation, which is highly expressed on neuroblastoma, melanoma, glioma, and small-cell lung cancer (SCLC) cells (35). On the other hand, the expression level of another disialoganglioside, GD3, is very low and restricted in adult extra neural tissues. Nevertheless, GD3 is highly expressed in tumor cells, accounting for more than $80 \%$ of melanomas. It is also overexpressed in neuroectodermal tumors (neuroblastoma and glioma) and carcinomas, including lung, breast, colon, prostate, and ovary cancers (36). In addition, GD3 expression was observed in T-cell acute lymphoblastic leukemia while being absent in non-T-cell malignancies (37). For these reasons, ganglioside GD3 has received considerable attention as being a promising immunotherapeutic target for cancer therapy. In addition, GM2 is another ganglioside overexpressed in a range of cancers, including melanoma and neuroblastoma (38).

Aberrant sialylation, both in glycoproteins and gangliosides, is closely associated with the malignant phenotypes of cancer cells, including metastatic potential and invasiveness. It was also established that the expression levels of specific neuraminidases, such as Neul and Neu3, are critical factors in the metastasis and survival of cancer cells, and that alteration in sialidase expression may be a defining factor for cancer progression, irrespective of the sialic acid content $(53,54)$.

The most common sialic acids in mammals are Neu5Ac and $N$-glycolylneuraminic acid (Neu5Gc), which are usually found as terminal constituents of different membrane glycoconjugates such as the GM3 ganglioside. Although $N$-glycolyl gangliosides are practically undetectable in normal human tissues as a result of an $A l u$-mediated inactivation of the gene coding for the enzyme CMP-NeuAc hydroxylase, these gangliosides are highly expressed in several human cancer cells (i.e., non-SCLC; Table 1) presumably due to incorporation of dietary Neu5Gc $(55,56)$. Furthermore, it has been proposed that the preferential expression of Neu5Gc in cancers is closely associated with tumor hypoxia, which induces expression of a sialic acid transporter and enhances the incorporation of non-human sialic acid from the external milieu (57). 
Table 1 | Gangliosides expressed in several types of human cancer cells.

\begin{tabular}{|c|c|c|c|c|c|c|c|c|c|c|c|}
\hline Type of tumor & GM3 & GM2 & GM1 & GD3 & GD2 & $\begin{array}{l}\text { 9-O- } \\
\text { Ac-GD3 }\end{array}$ & $\begin{array}{l}\text { 9-O- } \\
\text { Ac-GD2 }\end{array}$ & $\begin{array}{l}\text { 5-N- } \\
\text { de-GM3 }\end{array}$ & $\begin{array}{l}\text { Neu5Gc- } \\
\text { GM3 }\end{array}$ & $\begin{array}{l}\text { Fucosyl- } \\
\text { GM1 }\end{array}$ & Reference \\
\hline Melanoma & ++ & + & & ++++ & +++ & + & + & $++^{d}$ & ++ & & $\begin{array}{l}\text { Morton and Barth (39), } \\
\text { Pukel et al. (40), } \\
\text { Ravindranath et al. (41) }\end{array}$ \\
\hline Neuroblastoma & & ++ & & + & ++++ & + & & & & & $\begin{array}{l}\text { Cheung et al. (42), } \\
\text { Hettmer et al. (43), } \\
\text { Kohla et al. (44) }\end{array}$ \\
\hline Glioma & & & & ++ & ++++ & & & & & & Mujoo et al. (35) \\
\hline $\mathrm{SCLC}^{\mathrm{a}}$ & & ++ & ++ & ++ & +++ & & & & & +++ & $\begin{array}{l}\text { Brezicka et al. }(45), \\
\text { Yoshida et al. }(46,47)\end{array}$ \\
\hline Non-SCLC & +++ & & & & & & & & +++ & & van Cruijsen et al. (48) \\
\hline $\mathrm{T}^{-A L L^{b}}$ & & +++ & & ++ & + & & & & & & $\begin{array}{l}\text { Okada et al. (49), } \\
\text { Yamashiro et al. (50) }\end{array}$ \\
\hline $\mathrm{ATL}^{\mathrm{C}}$ & & & & ++ & ++ & & & & & & $\begin{array}{l}\text { Okada et al. (49), } \\
\text { Yamashiro et al. (50) }\end{array}$ \\
\hline Breast carcinoma & ++ & ++ & & ++ & & ++ & & & ++ & & Marquina et al. (51) \\
\hline Renal carcinoma & + & ++ & + & & & & & & & & Kudo et al. (52) \\
\hline
\end{tabular}

Plus signs represent ganglioside expression levels from weak (+) to strong $(++++)$ expression.

a Small cell lung cancer.

${ }^{b}$ T-cell acute lymphocytic leukemia.

${ }^{c}$ Adult T-cell leukemia.

${ }^{d} 5$-N-deacetylation of GM3 occurred in metastatic melanomas.

GD3 ganglioside can undergo 9-O-acetylation at $\mathrm{C} 9$ of the outer sialic acid (9-O-Ac-GD3) with enhanced expression of the 9$O$-acetylated form of GD3 ganglioside having been demonstrated in malignant melanomas and in basal cell carcinomas (58-60). Additional evidence also indicates that whereas GD3 enhances apoptosis, 9-O-acetyl-GD3 has the opposite effect (61).

Recently, it has been reported that 5-N-deacetylation of GM3 (5-N-de-GM3), specifically expressed in metastatic melanomas, but not in normal tissues or in the majority of primary melanomas or benign nevi, correlates with an enhanced metastatic phenotype. Furthermore, it has also been demonstrated that 5-N-de-GM3 stimulates cell migration and invasion by increasing the expression and activation of urokinase-like plasminogen activator and matrix metalloproteinase-2. Thus, $5-\mathrm{N}$-de-GM3 can be considered as a specific marker for metastatic melanoma and as a promising immunotherapeutic target for cancer therapy (62).

Fucosyl-GM1 is a ganglioside with a unique structure in which the terminal galactose is $\alpha-1,2$-fucosylated at the non-reducing end. It is expressed in very few normal tissues but occurs in a variety of cancers such as in SCLC. Consequently, fucosyl-GM1 has also been considered to be a candidate as a tumor marker and target antigen in antibody immunotherapy $(63,64)$.

\section{TUMOR-ASSOCIATED GANGLIOSIDES: MOLECULAR TARGETS FOR PASSIVE AND ACTIVE IMMUNOTHERAPIES}

The use of antibodies to specifically target different cell populations has become a desirable method for treatment of a variety of diseases, including cancer. In fact, cell surface receptors are the main targets for immunotherapy due to the fact that they often play important roles in tumor biology, where they are overexpressed or display abnormal signaling. Basically, immunotherapeutic strategies include the use of two types of immunization, passive and active, with passive immunity being the transfer of humoral immunity in the form of ready-made antibodies from one individual to another (natural), or achieved by the artificial transfer of antibodies that can be administered in several forms (human or animal plasma or serum, such as pooled human immunoglobulin or monoclonal antibodies). Passive immunotherapeutic can also include the use of unlabeled antibodies, radiolabeled antibodies, or antibody-drug conjugates, which is describe below. On the other hand, active immunization is the induction of humoral or cellular immunity after exposure to an antigen, which can occur both naturally and artificially.

Glycolipids in general and gangliosides in particular, have received considerable attention as a convenient immunotherapeutic target for cancer treatment. This has resulted in the development of a substantial number of potential passive and active immunotherapies (Table 2; Figure 2B), of which some are briefly described below.

\section{IMMUNOTHERAPIES USING GANGLIOSIDE GM3 AS THE TARGET}

GM3 can be defined as a tumor-associated carbohydrate antigen, since it is significantly overexpressed by a number of 
Table 2 | Immunotherapeutic strategies involving tumor associated gangliosides.

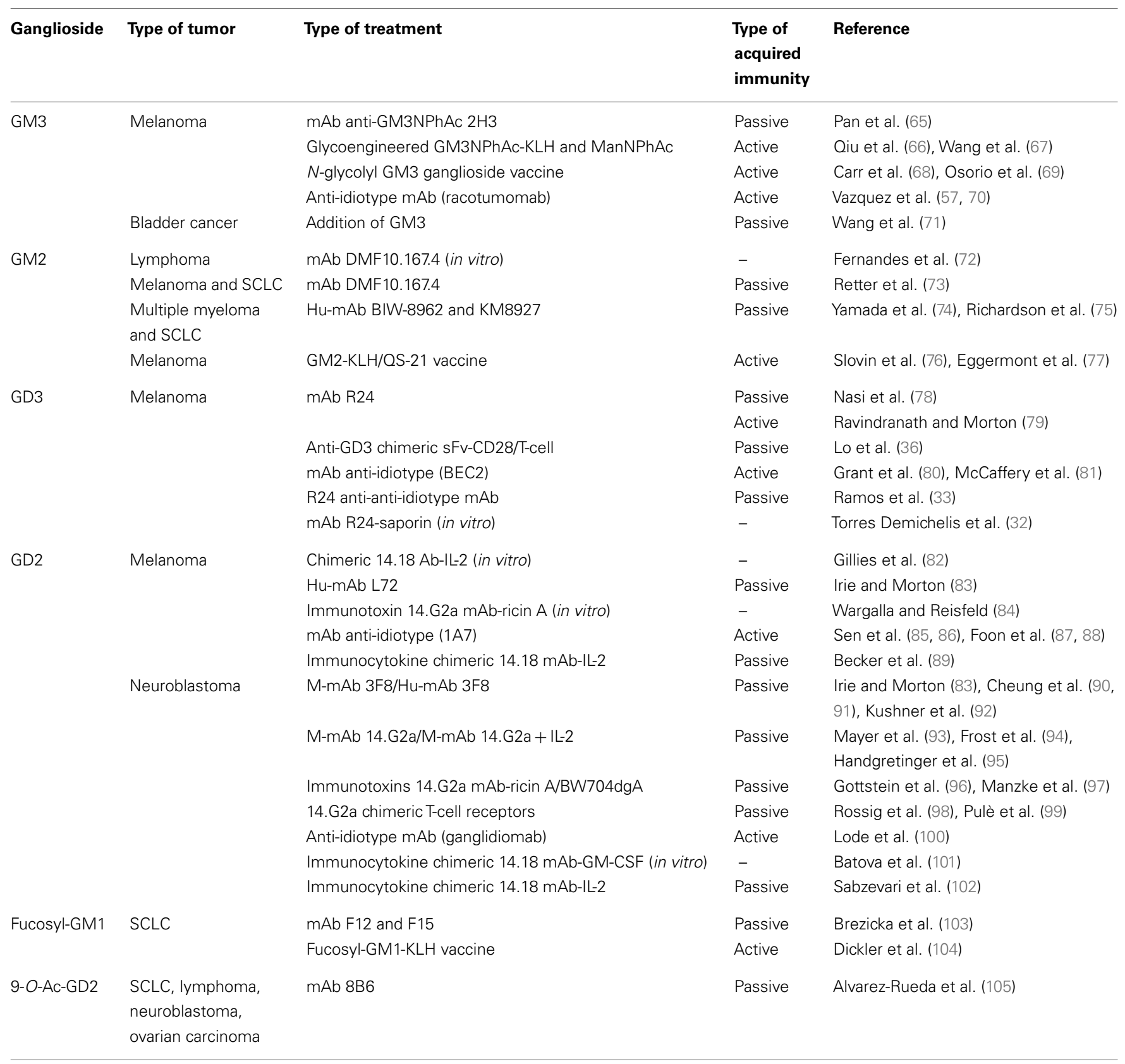

mAb, monoclonal antibody; $M$, mouse; Hu, human.

tumors, such as melanoma (39), and expressed at lower concentrations in many normal cells (106). It has been demonstrated that unnatural $N$-acyl derivatives of GM3, especially $N$-phenylacetyl GM3 (GM3NPhAc), were much more immunogenic than native GM3, and that GM3NPhAc could provoke a robust $\mathrm{T}$-cell dependent immune response in mice (65), which is critical for the anti-tumor activities of a cancer immunotherapy. More recently, some studies have demonstrated an efficient metabolic glycoengineering of GM3 on melanoma cells with monoclonal antibody-mediated selective killing of glycoengineered cancer cells. Basically, cells were metabolically labeled both in vivo and in vitro with $\mathrm{N}$-phenylacetyl-D-mannosamine (ManNPhAc) and then a monoclonal antibody $(2 \mathrm{H} 3)$, which recognizes both GM3NPhAc and ManNPhAc, was employed to selectively target and kill metabolically glycoengineered cancer cells $(66,67)$.

The immunogenic and toxicity profile of the heterophilic Neu5Gc-GM3 ganglioside vaccine in patients with advanced breast cancer was previously described. This vaccine, which is formulated by the combination of gangliosides with the outer membrane protein of Neisseria meningitides to form very small size proteoliposomes (VSSPs), resulted in acceptable safety outcomes. 
In addition, this technology permits an active immunotherapy that involves activation of the potent innate natural immune system (68). More recently, a Phase Ib/IIa clinical trial was carried out in patients with advanced cutaneous and ocular malignant melanomas in order to evaluate the immunogenicity and toxicity of an intramuscularly administered cancer vaccine composed of Neu5Gc-GM3/VSSP (69). The results obtained indicated the safety and immunogenicity of the vaccine and reinforced the position of gangliosides as targets for immunotherapy.

An attractive approach to generate an effective immune response against tumor-associated antigens involves the use of an anti-idiotype monoclonal antibody and appropriately selected anti-idiotypic antibodies that can act as tumor-associated antigen substitutes. As already mentioned above, although $N$-glycolyl gangliosides are practically undetectable in normal human tissues, these gangliosides are highly expressed in several human cancer cells. For example, racotumomab is an anti-idiotype monoclonal antibody specific to an antibody, which reacts to Neu5Gccontaining gangliosides, sulfatides, and other antigens expressed in tumors. This antibody was able to induce a strong anti-metastatic effect in tumor-bearing mice (70), and more recently, a Phase II/III multicenter double-blind clinical trial was conducted to evaluate the effects of racotumomab vaccine in the overall survival in patients with advanced non-SCLC. The results of this study showed a significant clinical benefit in the patients who were treated with the anti-idiotype vaccine (57).

\section{IMMUNOTHERAPIES USING GANGLIOSIDE GM2 AS THE TARGET}

Ganglioside GM2 is involved in cell adhesion and signal transduction, and it has also been reported to play a role in tumor metastasis. As normal cells express little GM2, it is an ideal target for anti-metastatic therapy. Related to this, DMF10.167.4 is a hamster monoclonal antibody raised against a murine T-cell lymphoma cell line and has been shown to induce apoptosis in vitro (72). This antibody was found to react with a GM2 epitope that is expressed on a large number of tumor cell lines, including human melanoma and SCLC, but not on normal primary lines or most normal tissues (73). It was shown to have immunotherapeutic potential, since it was able both to prevent tumors being established in vivo and to block the progression of established tumors.

The anti-metastatic effects of the two humanized antiganglioside GM2 antibodies, BIW-8962 and KM8927, have been recently investigated and compared with the chimeric anti-GM2 antibody KM966, in a mouse model of multiple organ metastases induced by GM2-expressing SCLC cells (74). These humanized antibodies inhibited the production of multiple organ metastases, increased the number of apoptotic cells, and prolonged the survival of the mice, which suggests that humanized anti-GM2 antibodies may be therapeutically useful for controlling multiple organ metastases of GM2-expressing SCLC.

GM2 ganglioside has also been used for vaccination in combination with a T-cell carrier such as keyhole limpet hemocyanin $(\mathrm{KLH})$, or with other adjuvants such as purified mycobacterial cell-wall skeleton or QS-21, a saponin-based adjuvant. The GM2-KLH vaccine not only induced a IgM response, but also induced durable IgG antibodies in most patients in early clinical trials (76). Nevertheless, a recent study shows that GM2-KLH/QS21 vaccination does not improve the outcome for patients with stage II melanoma (77).

\section{IMMUNOTHERAPIES USING GANGLIOSIDE GD3 AS THE TARGET}

The ganglioside GD3 is a glycolipid highly expressed during the early developmental stages of the central nervous system, when the neural cells proliferate actively. At later developmental stages, the GD3 content declines and other gangliosides become more abundant $(107,108)$ with the expression level of GD3 being very low and restricted in adult extra neural tissues. However, GD3 is highly expressed in tumor cells in more than $80 \%$ of melanomas. It is also overexpressed in neuroectodermal tumors (neuroblastoma and glioma) and carcinomas (36). For these reasons, ganglioside GD3 has received considerable attention as a promising immunotherapeutic target for cancer therapy. As such, it has been used for passive (78) and active (79) immunotherapy of melanoma cancer. However, the results obtained with this antibody therapy are modest (76), and the generation of new GD3-specific chimeric antigen receptors with improved efficacy in human primary T-lymphocytes is currently being evaluated (36).

Many studies have also involved the use of anti-idiotype vaccine in cancer patients, which mimics GD3 ganglioside (109). In particular, the monoclonal antibody Bec2 has been studied in melanoma and SCLC patients, where it induced specific anti-GD3 antibodies, but only in a low percentage of patients $(80,81)$. Later, a Phase III clinical trial with 515 SCLC patients revealed a major response to chemotherapy and chest radiation with this antibody. Although this trial failed to show any survival advantage for vaccinated patients, a trend toward prolonged survival was observed in those patients who developed the humoral response (110).

The mouse monoclonal R24 antibody (IgG3), directed against ganglioside GD3, is a validated tumor targeting agent that has shown strong cell surface reactivity for a range of human melanoma cell lines and other epithelial tumor cancer cells (40). It was demonstrated in our laboratory that, for different cell lines, the R24 antibody to GD3 was rapidly endocytosed after binding to the disialoganglioside at the cell surface before being sorted to early endosomes and later accumulated in REs (111). Therefore, its rapid internalization in cells precludes its use as a "naked therapeutic antibody," because when internalized it cannot link to pathways of complement- or cellular-dependent anticancer activities. However, we took advantage of the internalization feature of R24 antibody for selective delivery of the toxin saporin (a ribosome-inactivating protein) to GD3-expressing cells (32). This was carried out using a goat anti-mouse IgG antibody linked to the ribosome-inactivating toxin, and additionally, biotinylated R24 antibody was used for targeted delivery of streptavidin-saporin. This immunotoxin was found to be specifically cytotoxic for GD3expressing cells [human (SK-Mel-28) and mouse (B16) melanoma cells and Chinese hamster ovary-K1 cells] grown on 2D monolayers and for cells grown in attachment-free conditions. Thus, ganglioside GD3 emerge as a novel and attractive class of cell surface molecule for the targeted delivery of cytotoxic agents, and 
therefore, provides a rationale for future therapeutic intervention in cancer.

\section{IMMUNOTHERAPIES USING GANGLIOSIDE GD2 AS THE TARGET}

GD2 is a disialoganglioside normally expressed on skin melanocytes, neurons, and peripheral nerves. It is overexpressed in cancers such as neuroblastoma, melanoma, glioma, some types of non-SCLC (112) and also in sarcomas (64), and thus is a promising target to treat these types of cancers. In fact, targeting GD2 has the important advantage that is not shed by cells into the microenvironment (113), in contrast with other studied gangliosides (114). Many antibodies that target this ganglioside have been studied, with Hu-mAb L72 being shown to react specifically with ganglioside GD2 and have a strong cytotoxic effect on human melanoma cells in the presence of complement (83). The 3F8 antibody has been assessed in clinical trials in patients with neuroblastoma $(90,92)$. Humanizing m3F8 produced antiGD2 antibodies with an increased ADCC potential in vitro and anti-tumor activity in vivo, also reduced pain and human antimouse antibody side effects (91). However, in a recent report, posterior reversible encephalopathy syndrome (PRES) in neuroblastoma patients receiving anti-GD2 3F8 was documented (115). The use of 14.G2a mouse monoclonal antibody showed granulocyte mediated ADCC in neuroblastoma cells in vitro (93), and when administrated to patients concomitantly with IL-2 (94).

When the effect of an immunotoxin covalently linking ricin A chain toxin to 14.G2a mouse monoclonal antibody was evaluated, cytotoxic activity of this immunocomplex against human tumor cells was reported in vitro (84) and in a disseminated human neuroblastoma in a severe combined immunodeficiency (SCID) mice model (96). In addition, it was described the antitumoral capacity of two immunotherapeutic approaches using GD2 binding BW704 antibody conjugated to deglycosylated ricin A and to an anti-CD3 $\times$ anti-GD2 bispecific antibody that was capable of redirecting cytotoxic T-cells toward neuroblastoma cells. The results obtained in vitro and in vivo suggest a potential role of these immunotherapeutic agents in the treatment of minimal residual disease in the advanced stages of neuroblastoma (97).

Anti-idiotype antibodies have also been investigated with respect to their ability to overcome difficulties and activate an appropriate immune response when GD2 ganglioside is used as immunogen. In one study, ganglidiomab was generated following immunization of Balb/c mice with 14G2a and splenocytes were then harvested to generate hybridoma cells. It was demonstrated induction of a GD2-specific humoral immune response after vaccination of mice with ganglidiomab effective in mediating GD2-specific killing of neuroblastoma cells (100). In other investigations, the murine monoclonal anti-ganglioside GD2 antibody 14.G2a was used to generate the monoclonal anti-idiotype 1A7 (85) which has been used as an anti-idiotype vaccine in patients with advanced melanoma $(87,88)$. Immunization with this antiidiotype vaccine elicited a strong anti-GD2 antibody response that specifically reacted with tumor cells expressing GD2 with the results suggesting that this anti-idiotype vaccine may have a role in preventing disease progression and in increasing the survival time for patients with advanced malignant melanoma (87).
Antibody-cytokine fusion proteins, designed to achieve optimal biological effectiveness by combining the unique targeting ability of antibodies with the multifunctional activities of cytokines (82, 116), have been also used as cancer vaccine. In addition, immunocytokines have been generated by fusion of a human/mouse chimeric anti-ganglioside GD2 antibody (ch14.18) with cytokines GM-CSF and IL-2, and proved to be effective in killing GD2 positive cells in vitro by CDC and ADCC mediated by granulocytes (101). The ch14.18-IL-2 fusion protein was also shown to have provided anti-tumor effects in SCID mice bearing human tumor xenografts of neuroblastoma (102) and melanoma (89).

9-O-Ac-GD2 ganglioside is a modified GD2 ganglioside which is expressed in neuroblastoma, SCLC, melanoma, and renal carcinoma, but not in peripheral nerve fibers, ovarian carcinoma, or pancreatic carcinoma (105). A monoclonal antibody to $O$-acetylGD2, 8B6, was developed and showed (both in vitro and in vivo) anti-tumor properties that were comparable to those elicited by anti-GD2 14.G2a. More recently, it was further demonstrated that the $8 \mathrm{~B} 6$ antibody was very effective in suppression of tumor growth in mice by reducing the cell proliferation index and inducing apoptosis. Moreover, it was also observed that the lytic function of NK cells and complement were not a requirement for the in vivo activity of the 8 B6 antibody (117).

\section{IMMUNOTHERAPIES USING GANGLIOSIDE FUCOSYL-GM1 AS THE TARGET}

Fucosyl-GM1 is a characteristic glycolipid expressed in SCLC cells, which is detected with high frequency in SCLC in comparison with other cancers of the lung or in normal lungs or bronchus (with it only being sporadically expressed, if at all, in normal tissues) $(45,64)$. However, the immune system does not seems to be able to respond against this fucosylated glycolipid, as there is no production of auto-antibodies (118). The fact that it is an exclusively antigen expressed on SCLC cells turns it into an appropriate candidate for therapy. Related to this, two monoclonal antibodies against fucosyl-GM1 (F12 and 15) induced CDC and ADCC in fucosyl-GM1 expressing cell lines in vitro, and also conferred protection against tumor engraftment in a mouse model (103). In clinical trials of immunization with fucosyl-GM1-KLH conjugate, SCLC patients demonstrated serological IgM and IgG responses against fucosyl-GM1 and in vitro CDC of fucosyl-GM1 positive cell lines (104). When the conjugate was produced using synthetic fucosyl-GM1 (119), the IgM response and in vitro CDC were comparable to those obtained with the natural fucosyl-GM1 conjugate but without the IgG response. Finally, in a recent study, it was also suggested as a potential marker of hepatocellular carcinoma (120).

\section{CONCLUDING REMARKS}

Over recent decades, a substantial number of cancer immunotherapies have been developed, that have used the sialosylated glycolipids as the main target (see Table 2; Figure 2B). Although many of these therapies have failed to result in a significant effect on tumor development, others have led to promising results. We have learnt about how we can address an immune response to a specific cell surface ganglioside, but certainly, there is still much to do in terms of improving these immunotherapies. With the advent of modern technologies, new and combinatorial immunotherapies are 
currently being developed in an attempt to overcome some of the limitations of using glycolipids as vaccine antigen, such as their poor immunogenicity, low-affinity immunoglobulin responses, and immunotolerance. In this sense, mimetic peptides represent a very promising tool to overcome T-cell independence of some carbohydrate antigens. The development of DNA vaccine encoding designed peptide mimotope (minigene) of GD2 ganglioside has been demonstrated to be effective in inducing protective GD2 cross-reactive IgG antibody responses $(121,122)$. As also proposed, engineering the mimotope into a hybrid plasmid, which can also include cytotoxic T-lymphocyte epitopes from a tumor target itself, would be expected to build an effector response that could improve the tumor-protective immunity evoked by the minigene vaccine (121). Finally, studies are also being focused on the development of new strategies for therapeutic intervention in cancer, which propose the use gangliosides for targeted delivery of cytotoxic agents via specific antibodies (32), or eventually, via small-molecule cyclic peptide ligands (123).

\section{AUTHORS CONTRIBUTION}

Jose L. Daniotti, Aldo A. Vilcaes, Vanina Torres Demichelis, Fernando M. Ruggiero, and Macarena Rodriguez-Walker contributed to the conception and design of the work. All authors wrote, edited, and reviewed the final manuscript version.

\section{ACKNOWLEDGMENTS}

This work was supported in part by Grants from Secretaría de Ciencia y Tecnología (SECyT), Universidad Nacional de Córdoba (UNC), Consejo Nacional de Investigaciones Científicas y Técnicas (CONICET), and Agencia Nacional de Promoción Científica y Tecnológica (ANPCyT), Argentina. The authors wish to thank past and present members of Daniotti's lab who contributed with comments, data, and discussions. Jose L. Daniotti is a career investigator of CONICET (Argentina). We apologize to all colleagues whose relevant work could unfortunately not be cited here because of space limitations. We thank native speaker, Dr. Paul Hobson, for revision of the manuscript.

\section{REFERENCES}

1. Merrill AH Jr. Sphingolipid and glycosphingolipid metabolic pathways in the era of sphingolipidomics. Chem Rev (2011) 111(10):6387-422. doi:10.1021/ cr2002917

2. Ledeen RW, Wu G. Nuclear sphingolipids: metabolism and signaling. J Lipid Res (2008) 49(6):1176-86. doi:10.1194/jlr.R800009-JLR200

3. Daniotti JL, Iglesias-Bartolome R. Metabolic pathways and intracellular trafficking of gangliosides. IUBMB Life (2011) 63(7):513-20. doi:10.1002/iub.477

4. Maccioni HJ. Glycosylation of glycolipids in the Golgi complex. J Neurochem (2007) 103(Suppl 1):81-90. doi:10.1111/j.1471-4159.2007.04717.x

5. Tettamanti G. Ganglioside/glycosphingolipid turnover: new concepts. Glycoconj J (2004) 20(5):301-17. doi:10.1023/B:GLYC.0000033627.02765.cc

6. Halter D, Neumann S, van Dijk SM, Wolthoorn J, de Maziere AM, Vieira OV, et al. Pre- and post-Golgi translocation of glucosylceramide in glycosphingolipid synthesis. J Cell Biol (2007) 179(1):101-15. doi:10.1083/jcb.200704091

7. D’Angelo G, Polishchuk E, Di Tullio G, Santoro M, Di Campli A, Godi A, et al. Glycosphingolipid synthesis requires FAPP2 transfer of glucosylceramide. Nature (2007) 449(7158):62-7. doi:10.1038/nature06097

8. Svennerholm L. Ganglioside designation. Adv Exp Med Biol (1980) 125:11.

9. Yu RK, Tsai YT, Ariga T, Yanagisawa M. Structures, biosynthesis, and functions of gangliosides - an overview. J Oleo Sci (2011) 60(10):537-44. doi:10.5650/ jos.60.537
10. Crespo PM, Iglesias-Bartolome R, Daniotti JL. Ganglioside GD3 traffics from the trans-Golgi network to plasma membrane by a Rab11-independent and brefeldin A-insensitive exocytic pathway. J Biol Chem (2004) 279(46):47610-8. doi:10.1074/jbc.M407181200

11. Iglesias-Bartolome R, Trenchi A, Comin R, Moyano AL, Nores GA, Daniotti JL. Differential endocytic trafficking of neuropathy-associated antibodies to GM1 ganglioside and cholera toxin in epithelial and neural cells. Biochim Biophys Acta (2009) 1788(12):2526-40. doi:10.1016/j.bbamem.2009.09.018

12. Mayor S, Pagano RE. Pathways of clathrin-independent endocytosis. Nat Rev Mol Cell Biol (2007) 8(8):603-12. doi:10.1038/nrm2216

13. Crespo PM, Silvestre DC, Gil GA, Maccioni HJ, Daniotti JL, Caputto BL. cFos activates glucosylceramide synthase and glycolipid synthesis in PC12 cells. J Biol Chem (2008) 283(45):31163-71. doi:10.1074/jbc.M709257200

14. Uliana AS, Crespo PM, Martina JA, Daniotti JL, Maccioni HJ. Modulation of GalT1 and SialT1 sub-Golgi localization by SialT2 expression reveals an organellar level of glycolipid synthesis control. J Biol Chem (2006) 281(43):32852-60. doi:10.1074/jbc.M605805200

15. Sonnino S, Aureli M, Loberto N, Chigorno V, Prinetti A. Fine tuning of cell functions through remodeling of glycosphingolipids by plasma membraneassociated glycohydrolases. FEBS Lett (2010) 584(9):1914-22. doi:10.1016/j. febslet.2009.11.020

16. Vilcaes AA, Torres Demichelis V, Daniotti JL. Trans-activity of plasma membrane-associated ganglioside sialyltransferase in mammalian cells. $J$ Biol Chem (2011) 286(36):31437-46. doi:10.1074/jbc.M111.257196

17. Crespo PM, Torres Demichelis V, Daniotti JL. Neobiosynthesis of glycosphingolipids by plasma membrane-associated glycosyltransferases. J Biol Chem (2010) 285(38):29179-90. doi:10.1074/jbc.M110.123422

18. Furukawa K, Tokuda N, Okuda T, Tajima O. Glycosphingolipids in engineered mice: insights into function. Semin Cell Dev Biol (2004) 15(4):389-96. doi:10.1016/j.semcdb.2004.03.006

19. Proia RL. Glycosphingolipid functions: insights from engineered mouse models. Philos Trans R Soc Lond B Biol Sci (2003) 358(1433):879-83. doi:10.1098/ rstb.2003.1268

20. Daniotti JL, Crespo PM, Yamashita T. In vivo modulation of epidermal growth factor receptor phosphorylation in mice expressing different gangliosides. JCell Biochem (2006) 99(5):1442-51. doi:10.1002/jcb.21034

21. Lopez PH, Schnaar RL. Gangliosides in cell recognition and membrane protein regulation. Curr Opin Struct Biol (2009) 19(5):549-57. doi:10.1016/j.sbi.2009. 06.001

22. Regina Todeschini A, Hakomori SI. Functional role of glycosphingolipids and gangliosides in control of cell adhesion, motility, and growth, through glycosynaptic microdomains. Biochim Biophys Acta (2008) 1780(3):421-33. doi:10.1016/j.bbagen.2007.10.008

23. Yamashita T, Hashiramoto A, Haluzik M, Mizukami H, Beck S, Norton A, et al. Enhanced insulin sensitivity in mice lacking ganglioside GM3. Proc Natl Acad Sci U S A (2003) 100(6):3445-9. doi:10.1073/pnas.0635898100

24. Ziulkoski AL, Andrade CM, Crespo PM, Sisti E, Trindade VM, Daniotti JL, et al. Gangliosides of myelosupportive stroma cells are transferred to myeloid progenitors and are required for their survival and proliferation. Biochem J (2006) 394(Pt 1):1-9. doi:10.1042/BJ20051189

25. Zurita AR, Maccioni HJ, Daniotti JL. Modulation of epidermal growth factor receptor phosphorylation by endogenously expressed gangliosides. Biochem J (2001) 355(Pt 2):465-72. doi:10.1042/0264-6021:3550465

26. Cho JA, Chinnapen DJ, Aamar E, te Welscher YM, Lencer WI, Massol R. Insights on the trafficking and retro-translocation of glycosphingolipid-binding bacterial toxins. Front Cell Infect Microbiol (2012) 2:51. doi:10.3389/fcimb.2012. 00051

27. Spooner RA, Smith DC, Easton AJ, Roberts LM, Lord JM. Retrograde transport pathways utilised by viruses and protein toxins. Virol J (2006) 3:26. doi:10.1186/1743-422X-3-26

28. Fewou SN, Rupp A, Nickolay LE, Carrick K, Greenshields KN, Pediani J, et al. Anti-ganglioside antibody internalization attenuates motor nerve terminal injury in a mouse model of acute motor axonal neuropathy. JClin Invest (2012) 122(3):1037-51. doi:10.1172/JCI59110

29. Nores GA, Lardone RD, Comin R, Alaniz ME, Moyano AL, Irazoqui FJ. AntiGM1 antibodies as a model of the immune response to self-glycans. Biochim Biophys Acta (2008) 1780(3):538-45. doi:10.1016/j.bbagen.2007.09.008 
30. Zhang X, Kiechle FL. Review: glycosphingolipids in health and disease. Ann Clin Lab Sci (2004) 34(1):3-13.

31. Willison HJ, Yuki N. Peripheral neuropathies and anti-glycolipid antibodies. Brain (2002) 125(Pt 12):2591-625. doi:10.1093/brain/awf272

32. Torres Demichelis V, Vilcaes AA, Iglesias-Bartolome R, Ruggiero FM, Daniotti JL. Targeted delivery of immunotoxin by antibody to ganglioside GD3: a novel drug delivery route for tumor cells. PLoS One (2013) 8(1):e55304. doi:10.1371/journal.pone.0055304

33. Ramos AS, Parise CB, Travassos LR, Han SW, de Campos-Lima PO, de Moraes JZ. The idiotype (Id) cascade in mice elicited the production of anti-R24 Id and anti-anti-Id monoclonal antibodies with antitumor and protective activity against human melanoma. Cancer Sci (2011) 102(1):64-70. doi:10.1111/j.1349-7006.2010.01771.x

34. Zhang S, Helling F, Lloyd KO, Livingston PO. Increased tumor cell reactivity and complement-dependent cytotoxicity with mixtures of monoclonal antibodies against different gangliosides. Cancer Immunol Immunother (1995) 40(2):88-94. doi:10.1007/BF01520289

35. Mujoo K, Cheresh DA, Yang HM, Reisfeld RA. Disialoganglioside GD2 on human neuroblastoma cells: target antigen for monoclonal antibodymediated cytolysis and suppression of tumor growth. Cancer Res (1987) 47(4):1098-104.

36. Lo AS, Ma Q, Liu DL, Junghans RP. Anti-GD3 chimeric sFv-CD28/T-cell receptor zeta designer $\mathrm{T}$ cells for treatment of metastatic melanoma and other neuroectodermal tumors. Clin Cancer Res (2010) 16(10):2769-80. doi:10.1158/1078-0432.CCR-10-0043

37. Reaman GH, Taylor BJ, Merritt WD. Anti-GD3 monoclonal antibody analysis of childhood T-cell acute lymphoblastic leukemia: detection of a target antigen for antibody-mediated cytolysis. Cancer Res (1990) 50(1):202-5.

38. Portoukalian J, Zwingelstein G, Dore JF. Lipid composition of human malignant melanoma tumors at various levels of malignant growth. Eur J Biochem (1979) 94(1):19-23. doi:10.1111/j.1432-1033.1979.tb12866.x

39. Morton DL, Barth A. Vaccine therapy for malignant melanoma. CA Cancer J Clin (1996) 46(4):225-44. doi:10.3322/canjclin.46.4.225

40. Pukel CS, Lloyd KO, Travassos LR, Dippold WG, Oettgen HF, Old LJ. GD3, a prominent ganglioside of human melanoma. Detection and characterisation by mouse monoclonal antibody. J Exp Med (1982) 155(4):1133-47. doi:10.1084/jem.155.4.1133

41. Ravindranath MH, Tsuchida T, Morton DL, Irie RF. Ganglioside GM3:GD3 ratio as an index for the management of melanoma. Cancer (1991) 67(12):3029-35. doi:10.1002/1097-0142(19910615)67:12<3029::AIDCNCR2820671217>3.0.CO;2-8

42. Cheung NK, Saarinen UM, Neely JE, Landmeier B, Donovan D, Coccia PF. Monoclonal antibodies to a glycolipid antigen on human neuroblastoma cells. Cancer Res (1985) 45(6):2642-9.

43. Hettmer S, Ladisch S, Kaucic K. Low complex ganglioside expression characterizes human neuroblastoma cell lines. Cancer Lett (2005) 225(1):141-9. doi:10.1016/j.canlet.2004.11.036

44. Kohla G, Stockfleth E, Schauer R. Gangliosides with O-acetylated sialic acids in tumors of neuroectodermal origin. Neurochem Res (2002) 27(7-8):583-92. doi:10.1023/A:1020211714104

45. Brezicka FT, Olling S, Nilsson O, Bergh J, Holmgren J, Sorenson S, et al. Immunohistological detection of fucosyl-GM1 ganglioside in human lung cancer and normal tissues with monoclonal antibodies. Cancer Res (1989) 49(5):1300-5.

46. Yoshida S, Fukumoto S, Kawaguchi H, Sato S, Ueda R, Furukawa K. Ganglioside G(D2) in small cell lung cancer cell lines: enhancement of cell proliferation and mediation of apoptosis. Cancer Res (2001) 61(10):4244-52.

47. Yoshida S, Kawaguchi H, Sato S, Ueda R, Furukawa K. An anti-GD2 monoclonal antibody enhances apoptotic effects of anti-cancer drugs against small cell lung cancer cells via JNK (c-Jun terminal kinase) activation. Jpn J Cancer Res (2002) 93(7):816-24. doi:10.1111/j.1349-7006.2002.tb01324.x

48. van Cruijsen H, Ruiz MG, van der Valk P, de Gruijl TD, Giaccone G. Tissue micro array analysis of ganglioside $\mathrm{N}$-glycolyl GM3 expression and signal transducer and activator of transcription (STAT)-3 activation in relation to dendritic cell infiltration and microvessel density in non-small cell lung cancer. BMC Cancer (2009) 9:180. doi:10.1186/1471-2407-9-180

49. Okada M, Furukawa K, Yamashiro S, Yamada Y, Haraguchi M, Horibe K, et al. High expression of ganglioside alpha-2,8-sialyltransferase (GD3 synthase) gene in adult T-cell leukemia cells unrelated to the gene expression of human Tlymphotropic virus type I. Cancer Res (1996) 56(12):2844-8.

50. Yamashiro S, Ruan S, Furukawa K, Tai T, Lloyd KO, Shiku H. Genetic and enzymatic basis for the differential expression of GM2 and GD2 gangliosides in human cancer cell lines. Cancer Res (1993) 53(22):5395-400.

51. Marquina G, Waki H, Fernandez LE, Kon K, Carr A, Valiente O, et al. Gangliosides expressed in human breast cancer. Cancer Res (1996) 56(22): 5165-71.

52. Kudo D, Rayman P, Horton C, Cathcart MK, Bukowski RM, Thornton M, et al. Gangliosides expressed by the renal cell carcinoma cell line SK-RC45 are involved in tumor-induced apoptosis of T cells. Cancer Res (2003) 63(7):1676-83.

53. Miyagi T. Aberrant expression of sialidase and cancer progression. Proc Jpn Acad Ser B Phys Biol Sci (2008) 84(10):407-18. doi:10.2183/pjab.84.407

54. Yamaguchi K, Shiozaki K, Moriya S, Koseki K, Wada T, Tateno H, et al. Reduced susceptibility to colitis-associated colon carcinogenesis in mice lacking plasma membrane-associated sialidase. PLoS One (2012) 7(7):e41132. doi:10.1371/journal.pone.0041132

55. Fernandez LE, Gabri MR, Guthmann MD, Gomez RE, Gold S, Fainboim L, et al. NGcGM3 ganglioside: a privileged target for cancer vaccines. Clin Dev Immunol (2010) 2010:814397. doi:10.1155/2010/814397

56. Varki A. Colloquium paper: uniquely human evolution of sialic acid genetics and biology. Proc Natl Acad Sci U S A (2010) 107(Suppl 2):8939-46. doi:10.1073/pnas.0914634107

57. Vazquez AM, Hernandez AM, Macias A, Montero E, Gomez DE, Alonso DF, et al. Racotumomab: an anti-idiotype vaccine related to N-glycolylcontaining gangliosides - preclinical and clinical data. Front Oncol (2012) 2:150. doi:10.3389/fonc. 2012.00150

58. Chammas R, Sonnenburg JL, Watson NE, Tai T, Farquhar MG, Varki NM, et al. De-N-acetyl-gangliosides in humans: unusual subcellular distribution of a novel tumor antigen. Cancer Res (1999) 59(6):1337-46.

59. Cheresh DA, Reisfeld RA, Varki AP. O-acetylation of disialoganglioside GD3 by human melanoma cells creates a unique antigenic determinant. Science (1984) 225(4664):844-6. doi:10.1126/science.6206564

60. Varki NM, Varki A. Diversity in cell surface sialic acid presentations: implications for biology and disease. Lab Invest (2007) 87(9):851-7. doi:10.1038/ labinvest.3700656

61. Malisan F, Franchi L, Tomassini B, Ventura N, Condo I, Rippo MR, et al. Acetylation suppresses the proapoptotic activity of GD3 ganglioside. J Exp Med (2002) 196(12):1535-41. doi:10.1084/jem.20020960

62. Liu JW, Sun P, Yan Q, Paller AS, Gerami P, Ho N, et al. De-N-acetyl GM3 promotes melanoma cell migration and invasion through urokinase plasminogen activator receptor signaling-dependent MMP-2 activation. Cancer Res (2009) 69(22):8662-9. doi:10.1158/0008-5472.CAN-09-1099

63. Tokuda N, Zhang Q, Yoshida S, Kusunoki S, Urano T, Furukawa K. Genetic mechanisms for the synthesis of fucosyl GM1 in small cell lung cancer cell lines. Glycobiology (2006) 16(10):916-25. doi:10.1093/glycob/cwl022

64. Zhang S, Cordon-Cardo C, Zhang HS, Reuter VE, Adluri S, Hamilton WB, et al. Selection of tumor antigens as targets for immune attack using immunohistochemistry: I. Focus on gangliosides. Int J Cancer (1997) 73(1):42-9. doi:10.1002/(SICI) 1097-0215(19970926)73:1<42::AID-IJC8>3.0.CO;2- 1

65. Pan Y, Chefalo P, Nagy N, Harding C, Guo Z. Synthesis and immunological properties of N-modified GM3 antigens as therapeutic cancer vaccines. J Med Chem (2005) 48(3):875-83. doi:10.1021/jm0494422

66. Qiu L, Gong X, Wang Q, Li J, Hu H, Wu Q, et al. Combining synthetic carbohydrate vaccines with cancer cell glycoengineering for effective cancer immunotherapy. Cancer Immunol Immunother (2012) 61(11):2045-54. doi:10.1007/s00262-012-1224-6

67. Wang Q, Zhang J, Guo Z. Efficient glycoengineering of GM3 on melanoma cell and monoclonal antibody-mediated selective killing of the glycoengineered cancer cell. Bioorg Med Chem (2007) 15(24):7561-7. doi:10.1016/j.bmc.2007. 09.005

68. Carr A, Rodriguez E, Arango Mdel C, Camacho R, Osorio M, Gabri M, et al. Immunotherapy of advanced breast cancer with a heterophilic ganglioside (NeuGcGM3) cancer vaccine. J Clin Oncol (2003) 21(6):1015-21. doi:10.1200/JCO.2003.02.124

69. Osorio M, Gracia E, Rodriguez E, Saurez G, Arango Mdel C, Noris E, et al. Heterophilic NeuGcGM3 ganglioside cancer vaccine in advanced melanoma 
patients: results of a phase Ib/IIa study. Cancer Biol Ther (2008) 7(4):488-95. doi:10.4161/cbt.7.4.5476

70. Vazquez AM, Gabri MR, Hernandez AM, Alonso DF, Beausoleil I, Gomez DE, et al. Antitumor properties of an anti-idiotypic monoclonal antibody in relation to N-glycolyl-containing gangliosides. Oncol Rep (2000) 7(4): 751-6.

71. Wang H, Isaji T, Satoh M, Li D, Arai Y, Gu J. Antitumor effects of exogenous ganglioside GM3 on bladder cancer in an orthotopic cancer model. Urology (2013) 81(1):.e11-5. doi:10.1016/j.urology.2012.08.015

72. Fernandes DM, Baird AM, Berg LJ, Rock KL. A monoclonal antibody reactive with a $40-\mathrm{kDa}$ molecule on fetal thymocytes and tumor cells blocks proliferation and stimulates aggregation and apoptosis. J Immunol (1999) 163(3):1306-14.

73. Retter MW, Johnson JC, Peckham DW, Bannink JE, Bangur CS, Dresser $\mathrm{K}$, et al. Characterization of a proapoptotic antiganglioside GM2 monoclonal antibody and evaluation of its therapeutic effect on melanoma and small cell lung carcinoma xenografts. Cancer Res (2005) 65(14):6425-34. doi:10.1158/0008-5472.CAN-05-0300

74. Yamada T, Bando H, Takeuchi S, Kita K, Li Q, Wang W, et al. Genetically engineered humanized anti-ganglioside GM2 antibody against multiple organ metastasis produced by GM2-expressing small-cell lung cancer cells. Cancer Sci (2011) 102(12):2157-63. doi:10.1111/j.1349-7006.2011.02093.x

75. Richardson PG, Lonial S, Jakubowiak AJ, Harousseau JL, Anderson KC. Monoclonal antibodies in the treatment of multiple myeloma. Br J Haematol (2011) 154(6):745-54. doi:10.1111/j.1365-2141.2011.08790.x

76. Slovin SF, Keding SJ, Ragupathi G. Carbohydrate vaccines as immunotherapy for cancer. Immunol Cell Biol (2005) 83(4):418-28. doi:10.1111/j.1440-1711. 2005.01350.x

77. Eggermont AM, Suciu S, Rutkowski P, Marsden J, Santinami M, Corrie P, et al. Adjuvant ganglioside GM2-KLH/QS-21 vaccination versus observation after resection of primary tumor $>1.5 \mathrm{~mm}$ in patients with stage II melanoma: results of the EORTC 18961 randomized phase III trial. J Clin Oncol (2013) 31(30):3831-7. doi:10.1200/JCO.2012.47.9303

78. Nasi ML, Meyers M, Livingston PO, Houghton AN, Chapman PB. Antimelanoma effects of R24, a monoclonal antibody against GD3 ganglioside. Melanoma Res (1997) 7(Suppl 2):S155-62. doi:10.1097/00008390-19970800100024

79. Ravindranath $\mathrm{MH}$, Morton DL. Role of gangliosides in active immunotherapy with melanoma vaccine. Int Rev Immunol (1991) 7(4):303-29. doi:10.3109/ 08830189109114877

80. Grant SC, Kris MG, Houghton AN, Chapman PB. Long survival of patients with small cell lung cancer after adjuvant treatment with the anti-idiotypic antibody BEC2 plus bacillus Calmette-Guerin. Clin Cancer Res (1999) 5(6):1319-23.

81. McCaffery M, Yao TJ, Williams L, Livingston PO, Houghton AN, Chapman PB. Immunization of melanoma patients with BEC2 anti-idiotypic monoclonal antibody that mimics GD3 ganglioside: enhanced immunogenicity when combined with adjuvant. Clin Cancer Res (1996) 2(4):679-86.

82. Gillies SD, Reilly EB, Lo KM, Reisfeld RA. Antibody-targeted interleukin 2 stimulates T-cell killing of autologous tumor cells. Proc Natl Acad Sci U S A (1992) 89(4):1428-32. doi:10.1073/pnas.89.4.1428

83. Irie RF, Morton DL. Regression of cutaneous metastatic melanoma by intralesional injection with human monoclonal antibody to ganglioside GD2. Proc Natl Acad Sci U S A (1986) 83(22):8694-8. doi:10.1073/pnas.83.22.8694

84. Wargalla UC, Reisfeld RA. Rate of internalization of an immunotoxin correlates with cytotoxic activity against human tumor cells. Proc Natl Acad Sci U S A (1989) 86(13):5146-50. doi:10.1073/pnas.86.13.5146

85. Sen G, Chakraborty M, Foon KA, Reisfeld RA, Bhattacharya-Chatterjee MB. Induction of IgG antibodies by an anti-idiotype antibody mimicking disialoganglioside GD2. J Immunother (1998) 21(1):75-83. doi:10.1097/00002371199801000-00010

86. Sen G, Chakraborty M, Foon KA, Reisfeld RA, Bhattacharya-Chatterjee M. Preclinical evaluation in nonhuman primates of murine monoclonal antiidiotype antibody that mimics the disialoganglioside GD2. Clin Cancer Res (1997) 3(11):1969-76.

87. Foon KA, Lutzky J, Baral RN, Yannelli JR, Hutchins L, Teitelbaum A, et al. Clinical and immune responses in advanced melanoma patients immunized with an anti-idiotype antibody mimicking disialoganglioside GD2. J Clin Oncol (2000) 18(2):376-84.
88. Foon KA, Sen G, Hutchins L, Kashala OL, Baral R, Banerjee M, et al. Antibody responses in melanoma patients immunized with an anti-idiotype antibody mimicking disialoganglioside GD2. Clin Cancer Res (1998) 4(5):1117-24.

89. Becker JC, Pancook JD, Gillies SD, Mendelsohn J, Reisfeld RA. Eradication of human hepatic and pulmonary melanoma metastases in SCID mice by antibody-interleukin 2 fusion proteins. Proc Natl Acad Sci U S A (1996) 93(7):2702-7. doi:10.1073/pnas.93.7.2702

90. Cheung NK, Kushner BH, Yeh SD, Larson SM. 3F8 monoclonal antibody treatment of patients with stage 4 neuroblastoma: a phase II study. Int J Oncol (1998) 12(6):1299-306.

91. Cheung NK, Guo H, Hu J, Tassev DV, Cheung IY. Humanizing murine IgG3 anti-GD2 antibody m3F8 substantially improves antibody-dependent cell-mediated cytotoxicity while retaining targeting in vivo. Oncoimmunology (2012) 1(4):477-86. doi:10.4161/onci.19864

92. Kushner BH, Kramer K, Modak S, Cheung NK. Successful multifold dose escalation of anti-GD2 monoclonal antibody $3 \mathrm{~F} 8$ in patients with neuroblastoma: a phase I study. J Clin Oncol (2011) 29(9):1168-74. doi:10.1200/JCO.2010.28. 3317

93. Mayer P, Handgretinger R, Bruchelt G, Schaber B, Rassner G, Fierlbeck G. Activation of cellular cytotoxicity and complement-mediated lysis of melanoma and neuroblastoma cells in vitro by murine antiganglioside antibodies MB 3.6 and 14.G2a. Melanoma Res (1994) 4(2):101-6. doi:10.1097/00008390199404000-00004

94. Frost JD, Hank JA, Reaman GH, Frierdich S, Seeger RC, Gan J, et al. A phase I/IB trial of murine monoclonal anti-GD2 antibody 14.G2a plus interleukin-2 in children with refractory neuroblastoma: a report of the Children's Cancer Group. Cancer (1997) 80(2):317-33. doi:10.1002/(SICI)1097-0142(19970715) 80:2<317::AID-CNCR21>3.0.CO;2-W

95. Handgretinger R, Baader P, Dopfer R, Klingebiel T, Reuland P, Treuner J, et al. A phase I study of neuroblastoma with the anti-ganglioside GD2 antibody 14.G2a. Cancer Immunol Immunother (1992) 35(3):199-204. doi:10. 1007/BF01756188

96. Gottstein C, Schon G, Tawadros S, Kube D, Wargalla-Plate UC, Hansmann ML, et al. Antidisialoganglioside ricin A-chain immunotoxins show potent antitumor effects in vitro and in a disseminated human neuroblastoma severe combined immunodeficiency mouse model. Cancer Res (1994) 54(23):6186-93.

97. Manzke O, Russello O, Leenen C, Diehl V, Bohlen H, Berthold F. Immunotherapeutic strategies in neuroblastoma: antitumoral activity of deglycosylated ricin A conjugated anti-GD2 antibodies and anti-CD3xanti-GD2 bispecific antibodies. Med Pediatr Oncol (2001) 36(1):185-9. doi:10.1002/1096-911X(20010101) 36:1<185::AID-MPO1044>3.0.CO;2-J

98. Rossig C, Bollard CM, Nuchtern JG, Merchant DA, Brenner MK. Targeting of $\mathrm{G}(\mathrm{D} 2)$-positive tumor cells by human $\mathrm{T}$ lymphocytes engineered to express chimeric T-cell receptor genes. Int J Cancer (2001) 94(2):228-36. doi:10.1002/ijc. 1457

99. Pulè MA, Straathof KC, Dotti G, Heslop HE, Rooney CM, Brenner MK. A chimeric $\mathrm{T}$ cell antigen receptor that augments cytokine release and supports clonal expansion of primary human T cells. Mol Ther (2005) 12(5):933-41. doi:10.1016/j.ymthe.2005.04.016

100. Lode HN, Schmidt M, Seidel D, Huebener N, Brackrock D, Bleeke M, et al. Vaccination with anti-idiotype antibody ganglidiomab mediates a $\mathrm{GD}(2)$-specific anti-neuroblastoma immune response. Cancer Immunol Immunother (2013) 62(6):999-1010. doi:10.1007/s00262-013-1413-y

101. Batova A, Kamps A, Gillies SD, Reisfeld RA, Yu AL. The Ch14.18-GM-CSF fusion protein is effective at mediating antibody-dependent cellular cytotoxicity and complement-dependent cytotoxicity in vitro. Clin Cancer Res (1999) 5(12):4259-63.

102. Sabzevari H, Gillies SD, Mueller BM, Pancook JD, Reisfeld RA. A recombinant antibody-interleukin 2 fusion protein suppresses growth of hepatic human neuroblastoma metastases in severe combined immunodeficiency mice. Proc Natl Acad Sci U S A (1994) 91(20):9626-30. doi:10.1073/pnas.91. 20.9626

103. Brezicka FT, Holmgren J, Kalies I, Lindholm L. Tumor-cell killing by MAbs against fucosyl GM1, a ganglioside antigen associated with small-cell lung carcinoma. Int J Cancer (1991) 49(6):911-8. doi:10.1002/ijc.2910490619

104. Dickler MN, Ragupathi G, Liu NX, Musselli C, Martino DJ, Miller VA, et al. Immunogenicity of a fucosyl-GM1-keyhole limpet hemocyanin conjugate 
vaccine in patients with small cell lung cancer. Clin Cancer Res (1999) 5(10):2773-9.

105. Alvarez-Rueda N, Desselle A, Cochonneau D, Chaumette T, Clemenceau B, Leprieur S, et al. A monoclonal antibody to O-acetyl-GD2 ganglioside and not to GD2 shows potent anti-tumor activity without peripheral nervous system cross-reactivity. PLoS One (2011) 6(9):e25220. doi:10.1371/journal.pone. 0025220

106. Nores GA, Dohi T, Taniguchi M, Hakomori S. Density-dependent recognition of cell surface GM3 by a certain anti-melanoma antibody, and GM3 lactone as a possible immunogen: requirements for tumor-associated antigen and immunogen. J Immunol (1987) 139(9):3171-6.

107. Daniotti JL, Rosales Fritz V, Kunda P, Nishi T, Maccioni HJ. Cloning, characterization and developmental expression of alpha2,8 sialyltransferase (GD3 synthase, ST8Sia I) gene in chick brain and retina. Int J Dev Neurosci (1997) 15(6):767-76. doi:10.1016/S0736-5748(97)00027-0

108. Gravotta D, Landa CA, Panzetta P, Maccioni HJ. In vivo and in vitro expression of gangliosides in chick retina Mueller cells. J Neurochem (1989) 52(3):768-76. doi:10.1111/j.1471-4159.1989.tb02521.x

109. Chapman PB, Houghton AN. Induction of IgG antibodies against GD3 ganglioside in rabbits by an anti-idiotypic monoclonal antibody. J Clin Invest (1991) 88(1):186-92. doi:10.1172/JCI115276

110. Giaccone G, Debruyne C, Felip E, Chapman PB, Grant SC, Millward M, et al. Phase III study of adjuvant vaccination with Bec2/bacille CalmetteGuerin in responding patients with limited-disease small-cell lung cancer (European Organisation for Research and Treatment of Cancer 0897108971B; Silva Study). J Clin Oncol (2005) 23(28):6854-64. doi:10.1200/JCO. 2005.17.186

111. Iglesias-Bartolome R, Crespo PM, Gomez GA, Daniotti JL. The antibody to GD3 ganglioside, R24, is rapidly endocytosed and recycled to the plasma membrane via the endocytic recycling compartment. Inhibitory effect of brefeldin A and monensin. FEBS J (2006) 273(8):1744-58. doi:10.1111/j.1742-4658.2006. 05194.x

112. Cheresh DA, Rosenberg J, Mujoo K, Hirschowitz L, Reisfeld RA. Biosynthesis and expression of the disialoganglioside GD2, a relevant target antigen on small cell lung carcinoma for monoclonal antibody-mediated cytolysis. Cancer Res (1986) 46(10):5112-8.

113. Kramer K, Gerald WL, Kushner BH, Larson SM, Hameed M, Cheung NK. Disialoganglioside G(D2) loss following monoclonal antibody therapy is rare in neuroblastoma. Clin Cancer Res (1998) 4(9):2135-9.

114. Portoukalian J, Zwingelstein G, Abdul-Malak N, Dore JF. Alteration of gangliosides in plasma and red cells of humans bearing melanoma tumors. Biochem Biophys Res Commun (1978) 85(3):916-20. doi:10.1016/0006291X(78)90630-7

115. Kushner BH, Modak S, Basu EM, Roberts SS, Kramer K, Cheung NK. Posterior reversible encephalopathy syndrome in neuroblastoma patients receiving anti-GD2 3F8 monoclonal antibody. Cancer (2013) 119(15):2789-95. doi:10.1002/cncr.28137
116. Gillies SD, Young D, Lo KM, Roberts S. Biological activity and in vivo clearance of antitumor antibody/cytokine fusion proteins. Bioconjug Chem (1993) 4(3):230-5. doi:10.1021/bc00021a008

117. Cochonneau D, Terme M, Michaud A, Dorvillius M, Gautier N, Frikeche J, et al. Cell cycle arrest and apoptosis induced by O-acetyl-GD2-specific monoclonal antibody 8B6 inhibits tumor growth in vitro and in vivo. Cancer Lett (2013) 333(2):194-204. doi:10.1016/j.canlet.2013.01.032

118. Adler G, Pacuszka T, Lewartowska A, Rowinska E, Oblakowski P, Panasiewicz M. Small cell lung cancer is not associated with the presence of anti-fucosyl-GM1 ganglioside autoantibodies reactive in immunoenzymatic test. Lung Cancer (2001) 34(3):383-5. doi:10.1016/S0169-5002(01)00264-1

119. Krug LM, Ragupathi G, Hood C, Kris MG, Miller VA, Allen JR, et al. Vaccination of patients with small-cell lung cancer with synthetic fucosyl GM-1 conjugated to keyhole limpet hemocyanin. Clin Cancer Res (2004) 10(18 Pt 1):6094-100. doi:10.1158/1078-0432.CCR-04-0482

120. Wu CS, Yen CJ, Chou RH, Li ST, Huang WC, Ren CT, et al. Cancer-associated carbohydrate antigens as potential biomarkers for hepatocellular carcinoma. PLoS One (2012) 7(7):e39466. doi:10.1371/journal.pone.0039466

121. Bolesta E, Kowalczyk A, Wierzbicki A, Rotkiewicz P, Bambach B, Tsao CY, et al. DNA vaccine expressing the mimotope of GD2 ganglioside induces protective GD2 cross-reactive antibody responses. Cancer Res (2005) 65(8):3410-8. doi:10.1158/0008-5472.CAN-04-2164

122. Kozbor D. Cancer vaccine with mimotopes of tumor-associated carbohydrate antigens. Immunol Res (2010) 46(1-3):23-31. doi:10.1007/s12026-009-8120-y

123. Tong W, Gagnon M, Sprules T, Gilbert M, Chowdhury S, Meerovitch K, et al. Small-molecule ligands of GD2 ganglioside, designed from NMR studies, exhibit induced-fit binding and bioactivity. Chem Biol (2010) 17(2):183-94. doi:10.1016/j.chembiol.2010.01.012

Conflict of Interest Statement: The authors declare that the research was conducted in the absence of any commercial or financial relationships that could be construed as a potential conflict of interest.

Received: 09 November 2013; paper pending published: 25 November 2013; accepted: 03 December 2013; published online: 19 December 2013.

Citation: Daniotti JL, Vilcaes AA, Torres Demichelis V, Ruggiero FM and RodriguezWalker M (2013) Glycosylation of glycolipids in cancer: basis for development of novel therapeutic approaches. Front. Oncol. 3:306. doi: 10.3389/fonc.2013.00306

This article was submitted to Molecular and Cellular Oncology, a section of the journal Frontiers in Oncology.

Copyright (๑) 2013 Daniotti, Vilcaes, Torres Demichelis, Ruggiero and RodriguezWalker. This is an open-access article distributed under the terms of the Creative Commons Attribution License (CC BY). The use, distribution or reproduction in other forums is permitted, provided the original author(s) or licensor are credited and that the original publication in this journal is cited, in accordance with accepted academic practice. No use, distribution or reproduction is permitted which does not comply with these terms. 